\title{
A COMPARISON OF HELICOPTER MAIN ROTOR FEATURES DUE TO STIFFNESS OF ROTOR BLADE-HUB CONNECTION
}

\author{
Jarosław Stanisławski \\ Institute of Aviation \\ al. Krakowska 110/114, 02-256 Warsaw, Poland \\ jaroslaw.stanislawski@ilot.edu.pl
}

\begin{abstract}
The paper presents results of simulation calculations concerning an influence of stiffness of bladehub connection on rotor loads and blades deflections in hover, level flight and pull up maneuver. The three versions of rotor are considered with articulated, elastic and stiff connections of blades and hub. The blades with the same distributions of stiffness, mass and the same aerodynamic characteristics are applied for all rotor cases. The rotor loads are calculated applying Runge-Kutta method to solve the equations of motion of deformable blades. According to the Galerkin method, the parameters of blades motion are treated as combination of considered blade bending and torsion eigen modes. The results of calculations indicate for possibility to generate the greater rotor control moments and to improve helicopter maneuverability in the case of applying the non-changed blade of articulated rotor combined with elastic rotor hub.
\end{abstract}

Keywords: helicopter, main rotor, blade deformations.

\section{INTRODUCTION}

A main rotor can be considered as a decisive unit of helicopter structure affecting rotorcraft performance. Rotating blades generate at rotor hub the resultant forces and moments which enable in-flight balance and control of helicopter. In the case of single rotor helicopter scheme, the tail rotor must be added to achieve directional control. Among the factors influencing on the level of rotor loads, it can be noticed: blade geometry, applied airfoils, shaft rotating speed, blade mass and stiffness, number of blades, and type of blade-hub connections. In flight, variable airflow conditions of blade sections are formed as the resultant velocity of rotor whirling and helicopter flight speed. Additional a cyclic and collective control of blade pitch affect generation of aerodynamic and inertial loads, which depend on an azimuthal position of blade on rotor disk. The number of rotor blades and properties of blade-hub connections strongly influence the level of loads transmitted from blades through hub to helicopter 
fuselage. For an articulated rotor hub the blade is attached through horizontal hinge (flapping), vertical hinge (lagging) and axial hinge which allow blade motion for out-of-plane and in-plane oscillations and for change of blade pitch. Applying set of hinges enables reduction of rotor loads components, pitching and rolling moments, transmitted to fuselage. Conventional articulated rotor head with builtin hinges demands frequent maintenance which increases costs of helicopter operation. A complex structure with large amount of component parts increases mass of articulated rotor. Aim to limit the deficiencies of articulated rotors, new designs of hingeless or bearingless rotors were developed with a view to achieve reduction of weight, maintenance and operational costs.

The descriptive comparison of features for helicopters with articulated rotor head and for helicopter with elastic elements connecting blades and rotor hub can be found in book issue [1] of R.W. Prouty's series of papers published in Rotor \& Wing magazine edited by AHS (American Helicopter Society).

Magnitudes of pitch and roll moments which are generated at rotor hub due to cyclic control of blade pitch angle and resulting deflections of rotor blade tips plane, are the main factors affecting helicopter dynamic characteristics. Size of moments generated at the rotor hub determines level of helicopter angular accelerations achievable during controlled maneuvers. Johnson [2] compared results of calculations concerning maneuverability of helicopter with articulated and elastic rotor head. The data received during flight tests of helicopters with different type of rotor head (Puma, Lynx, Bo-105) were published by G.R.Padfield [3]. The significant feature of hingeless rotor, applied to the German MBB Bo105 helicopter, is flexibility of the blade root sections attached to central hub block which enables replacing flapping and lagging hinges. The BK-117 German-Japanese helicopter is driven by the similar hingeless rotor system. The French company Aerospatiale, later branch of the Eurocopter, designed rotor-head of simplified structure Starflex and next Spheriflex [4] which allow weight reduction and maintenance cost saving. The Starflex rotor comprises a glassfibre star with flexible arms allowing flap motion and elastomeric bearings for blade pitch and lead-lag movements. In Spheriflex rotor the loads of each blade are transmitted to the hub by a single spherical elastomeric bearing which permits pitching, flapping and lead-lag motion. The German MBB firm developed FEL rotor (Fibre Elastomeric Bearing Rotor) with composite structure of hub and elastomeric bearings which was applied to Tigre helicopter [5]. The Eurocopter accomplished research program ATR (Advanced Technology Rotor) [6] including tests of bearingless five-bladed rotor for helicopter of four-ton mass class (EC-145). For the Lynx helicopter the special rotor was designed in which flap blade motion is permitted due to deflections of star-shaped titanium hub arms while in-plane motion is governed by stiffness of the circular-section titanium spigots which connect the blades to the hub [7]. Prediction of rotor dynamics and blade loads can be obtained using computational methods. For some types of helicopters, the comparison of calculated results (CAMRAD - Comprehensive Analytical Model of Rotorcraft Aerodynamics and Dynamics) and measured data of flight tests or tunnel research was conducted [8] which concerns the changes of torsion and bending blade moments for conditions of moderate $(\mu=0,15)$ and high $(\mu=0,36)$ flight speed. The best accordance of the calculated and measured results was received for rotor disk distribution of the out-of-plane blade bending moments. Among designs of the bearingless rotors the five-bladed rotor MDART (McDonnell Douglas Advanced Rotor Technology) of the MD-900 Explorer helicopter can be noticed. A freedom of blade motion for flap, lead-lag and pitch is provided by carbonfibre flex-beam connecting blade and central hub. Control moments for blade pitch changes is applied through the sleeve which covers inside the beam connecting blade and hub. Using data of MDART rotor an accuracy of calculation methods of UMARC (University of Maryland Advanced Code) and DART (Dynamics Analysis Research Tool) was evaluated for conditions of hover 
and level flight at speed $360 \mathrm{~km} / \mathrm{h}$. The computed values of blade loads and rotor hub vibration level were compared with data collected during tests in NASA Ames $40 \times 80$ feet wind tunnel [9].

The paper presents the results of calculations conducted for three types of rotors: articulated, elastic and stiff which comprise blade-hub connections of different stiffness. The blades of the same aerodynamic, mass and stiffness data were assumed for all versions of rotors. The rotor blades of similar characteristics were applied during ground and flight tests of the ILX-27 helicopter developed in Poland [10]. The method of calculation of rotor loads developed in Institute of Aviation was applied in earlier works [11], [12]. The performed calculations were focused on checking the possibility of usage the blades designed for articulated rotor, without changes their parameters, as an assembly with modified the elastic or stiff rotor head which should improve maneuverability of helicopter in comparison with one of articulated rotor. The stiff rotor is treated as the extreme case showing the scale of changes of blade loads and deformations due to stiffness increase of the blade-hub connections. the computer simulations were conducted for the following cases of helicopter flight: hover conditions, level flight at speed of $180 \mathrm{~km} / \mathrm{h}$ and the final phase of pull-up maneuver at speed of $100 \mathrm{~km} / \mathrm{h}$.

\section{METHOD OF CALCULATION}

The model of the main rotor comprises blades and arms of rotor head. The algorithm of calculations includes an multi-blade analysis in which, for given moment of time, parameters of motion and loads are computed for the individual blades taking their position at different azimuth angles on the rotor disk. A sum of reactions from the all blades yields the resultant loads of the main rotor hub at the concerned moment of time. The physical model of rotor blade is shown in Fig.1.

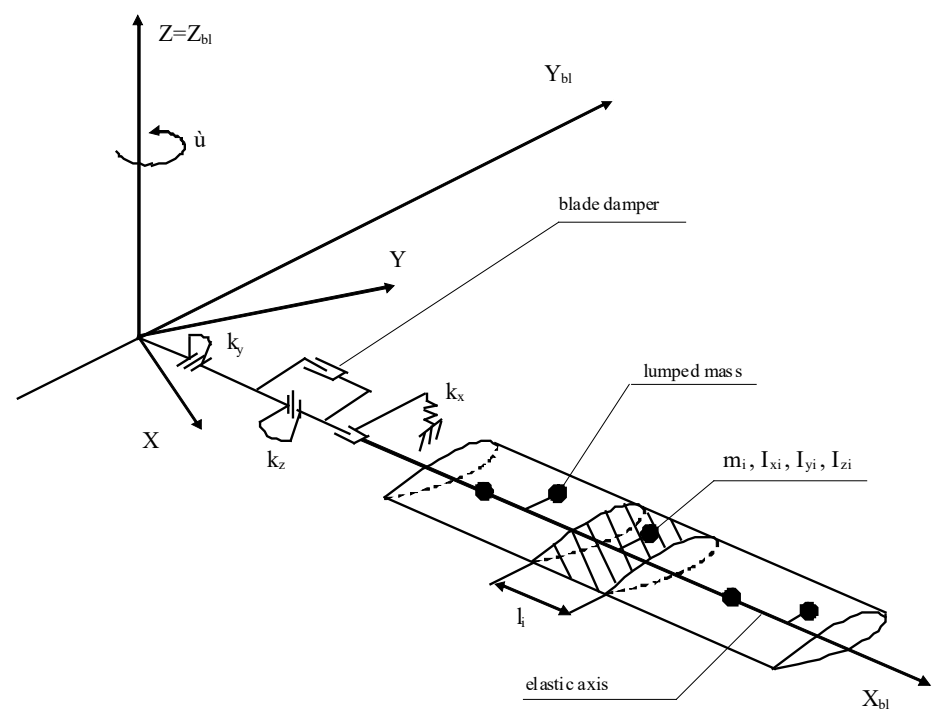

Fig. 1. Physical model of rotor blade with lumped masses along blade elastic axis, blade segment data: length $l_{i}$, mass $m_{i}$, second mass moments of inertia $I_{x i}, I_{y i}, I_{z i}$ [author] 
Defining the blade model the following assumptions are applied:

- mass distribution of the blade is replaced by lumped masses representing inertial features of corresponding blade segments,

- lumped masses are located at the centers of gravity of blade segments,

- lumped masses are connected with elastic axis which represents torsion and bending stiffness of blade in thrust and revolution planes,

- rotor hub and blade are connected to each other by articulated joints which can be modified by introducing the spring elements influencing flap and lead-lag motion of blade,

- blade dampers are applied to limit lead-lag motion of blades,

- in non-deformed state the blade elastic axis is coincident with the blade pitch axis.

The mathematical model includes the equations of motion of the elastic axes of deformable blades which can be derived applying Lagrange formula:

$$
\frac{d}{d t}\left(\frac{\partial T}{\partial q_{i}^{\&}}\right)-\frac{\partial T}{\partial q_{i}}+\frac{\partial U}{\partial q_{i}}=Q_{i} \mathrm{i}=1, \ldots, \mathrm{n}
$$

where

$\mathrm{T}$ - rotor kinetic energy, $\mathrm{U}$ - rotor potential energy,

$\mathrm{q}_{\mathrm{i}}$ - generalized coordinate, $\mathrm{Q}_{\mathrm{i}}$ - generalized force,

$\mathrm{n}$ - number of generalized coordinates.

The potential energy of the elastic axis being subjected to torsion and bending is equal:

$$
U=\int_{0}^{R} \frac{M_{Y}^{2}}{2 E J_{Y}} d x+\int_{0}^{R} \frac{M_{Z}^{2}}{2 E J_{Z}} d x+\int_{0}^{R} \frac{M_{S}^{2}}{2 G J_{X}} d x
$$

The torsion and bending moments, acting at cross sections of the elastic axis, can be defined due to corresponding deformations: twist angle $\varphi$, in-plane y deflections and out-of-plane $\mathrm{z}$ deflections:

$$
M_{Y}=E J_{Y} \frac{d^{2} z}{d x^{2}}, M_{Z}=E J_{Z} \frac{d^{2} y}{d x^{2}}, M_{S}=G J_{X} \frac{d \varphi}{d x}
$$

Substituting equations (3) into formula (2) yields the following form:

$$
U=\frac{1}{2} \int_{0}^{R} E J_{Y}\left(\frac{d^{2} z}{d x^{2}}\right)^{2} d x+\frac{1}{2} \int_{0}^{R} E J_{Z}\left(\frac{d^{2} y}{d x^{2}}\right)^{2} d x+\frac{1}{2} \int_{0}^{R} G J_{X}\left(\frac{d \varphi}{d x}\right)^{2} d x
$$

The kinetic energy of twisted and bent axis can be expressed as follows: 


$$
T=\frac{1}{2} \int_{0}^{R} m(x) V_{Y}^{2}(x) d x+\frac{1}{2} \int_{0}^{R} m(x) V_{Z}^{2}(x) d x+\frac{1}{2} \int_{0}^{R} I_{X}(x) \Omega_{\varphi}^{2}(x) d x
$$

After substitution Eqs.(4) and (5) into Eqs.(1) the equations of motion of elastic blade are given as follows:

$$
\begin{aligned}
& \int_{0}^{R} m(x)^{\&} y^{\&} d x+\int_{0}^{R} \frac{d^{2}}{d x^{2}}\left[E J_{Z}\left(\frac{d^{2} y}{d x^{2}}\right)\right] d x=\int_{0}^{R}\left(F_{Y_{E X T}}(x)-F_{Y_{I}}(x)\right) d x, \\
& \int_{0}^{R} m(x)^{\&} z^{\&} d x+\int_{0}^{R} \frac{d^{2}}{d x^{2}}\left[E J_{Y}\left(\frac{d^{2} z}{d x^{2}}\right)\right] d x=\int_{0}^{R}\left(F_{Z_{E X T}}(x)-F_{Z_{I}}(x)\right) d x, \\
& \int_{0}^{R} I_{X}(x)^{\&} \varphi^{\&} d x+\int_{0}^{R} \frac{d}{d x}\left[G J_{X}\left(\frac{d \varphi}{d x}\right)\right] d x=\int_{0}^{R}\left(M_{S_{E X T}}(x)-M_{S_{I}}(x)\right) d x,
\end{aligned}
$$

where

$\mathrm{F}_{\mathrm{YEXT}}, \mathrm{F}_{\mathrm{ZEXT}}, \mathrm{M}_{\mathrm{SEXT}}$ - shearing forces and torsion moment of external loads acting on element $\mathrm{dx}$ of blade axis,

$\mathrm{F}_{\mathrm{YI}}, \mathrm{F}_{\mathrm{ZI}}, \mathrm{M}_{\mathrm{SI}}$ - inertial shear forces and torsion moment without corresponding components

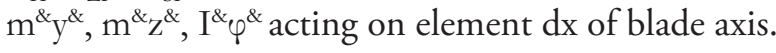

In the case of the rotating elastic axis, to the equations of motion must comprise components which consider the stiffening effects of centrifugal forces. The centrifugal forces acting per unit length which reduce bending moments of deformed blade axis are equal:

$$
\text { for the out-of-plane case } p_{Z_{\Omega}}=\frac{d}{d x}\left(N \frac{d z}{d x}\right)
$$

$$
\text { for the in-plane case } \quad p_{Y_{\Omega}}=\frac{d}{d x}\left(N \frac{d y}{d x}\right)-m(x) \omega^{2} y,
$$

where

$N=\int_{r}^{R} m(x) \omega^{2} x d x$ - the centrifugal force for blade cross section in distance $r$ from axis of the rotor shaft.

The system of equations (6) with added formulas (7) concerns the case of the elastic axis with the continuous distribution of mass. Solution of this equation system can be found by applying Galerkin's method in which deflections of the elastic axis $y, z, \varphi$ are assumed to be equal to the sums of component deformations deriving from the considered eigen modes of the blade vibration: 


$$
y(x, t)=\sum_{i 1=1}^{I 1} \rho_{i 1}(t) y_{i 1}(x) ; \mathrm{z}(\mathrm{x}, \mathrm{t})=\sum_{\mathrm{i} 2=1}^{\mathrm{I} 2} \delta_{\mathrm{i} 2}(\mathrm{t}) \mathrm{z}_{\mathrm{i} 2}(\mathrm{x}) ; \varphi(\mathrm{x}, \mathrm{t})=\sum_{\mathrm{i} 3=1}^{\mathrm{I} 3} \eta_{\mathrm{i} 3}(\mathrm{t}) \varphi_{\mathrm{i} 3}(\mathrm{x})
$$

where

$y_{i 1}, z_{i 2}, j_{i 3}$ - eigen modes respectively for in-plane bending, out-of plane bending and torsion;

$\rho_{\mathrm{i} 1}, \delta_{\mathrm{i} 2}, \eta_{\mathrm{i} 3}$ - time dependent shares of the each eigen mode which are being determined in computing process;

I1, I2, I3 - the numbers of considered bending and torsion eigen modes of rotor blade.

Applying the orthogonality relation of eigen modes equations (6) can be transformed to a set of differential equations which are referred to each of considered the blade eigen modes:

- for out-of-plane bending

$$
\underset{R^{+}}{\&} \rho_{i 1} p_{i 1}^{2}=Q_{Y_{i 1}}, \mathrm{il}=1, \ldots, \mathrm{Il}
$$

- for in-plane bending

$$
\stackrel{\&}{\&}+\delta_{i 2} f_{i 2}^{2}=Q_{Z_{i 2}}, \mathrm{i} 2=1, \ldots, \mathrm{I} 2
$$

- for torsion

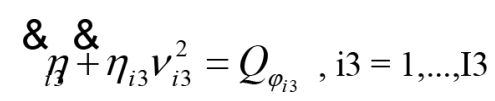

The equations of blade motion (9) are solved by applying Runge-Kutta method. After computing for a given moment of time the value of the shares for displacements $\rho, \delta, \eta$, velocities $\rho^{\&}, \delta^{\&}, \eta^{8}$ and accelerations ${ }^{8} \rho^{\&},{ }^{8} \delta^{\&},{ }^{8} \eta^{8}$ the resultant parameters of the blade motion can be determined. At the next time steps, repeating the cycle of calculation allows to obtain simulated time-runs of deformations and loads of blades and time-runs of resultant rotor shaft loads.

The aerodynamic forces, acting on the blade segment at a given azimuth position on the rotor disk, are calculated by applying the blade element theory. The local angle of attack depends on temporary blade pitch and on conditions of the cross-section airflow:

$$
\alpha=\varphi_{g t w}+\varphi-\operatorname{arctg}\left(\frac{v_{Z}}{v_{X}}\right),
$$

where

$\varphi_{\mathrm{gtw}}$ - geometric twist,

$\mathrm{v}_{\mathrm{Z}}, \mathrm{v}_{\mathrm{X}}$ - vertical and horizontal components of airflow,

$\varphi$ - temporary pitch angle due to deformations and applied control. 
Pitch angle of a blade element is defined as follows:

$$
\varphi=\varphi_{\mathrm{o}}+\varphi_{\mathrm{x}} \cos (\omega \mathrm{t})+\varphi_{\mathrm{y}} \sin (\omega \mathrm{t})+\varphi_{\mathrm{def}}-\mathrm{k} \beta
$$

where

$\varphi_{\mathrm{o}}$ - collective control angle,

$\varphi_{\mathrm{x}}, \varphi_{\mathrm{y}}$ - cyclic control angle due to roll and pitch deflection of the swashplate,

$\varphi_{\text {def }}$ - angle of torsion deformation at cross-section of blade,

$\mathrm{k}$ - coefficient of coupling flapping and blade pitching,

$\beta$ - temporary blade flapping angle at horizontal hinge of rotor head.

\section{COMPARISON OF ROTOR FEATURES}

For simulation calculations concerning features of rotors with different types of the rotor heads, were performed for the aerodynamic , mass and stiffness data of blades of light helicopter with mass of $1,100 \mathrm{~kg}$ and with three-bladed articulated rotor is treated as the basic version. It is assumed that basic rotor will be modified by introducing at position of flap and lead-lag hinges the additional elements which change the stiffness of modeled hub arms. For the all cases of rotor the radius is assumed to be the same ( $\mathrm{R}=3.73 \mathrm{~m})$. The same set of blades with unchanged characteristics is preserved for all variants of rotor hub. Three types of the main rotor are considered relating to difference of the blade-hub connection stiffness:

- articulated rotor $\left(\mathrm{k}_{\mathrm{y}}=\mathrm{k}_{\mathrm{z}}=0[\mathrm{Nm} / \mathrm{rad}]\right)$,

- elastic rotor with spring elements replacing hinges $\left(\mathrm{k}_{\mathrm{y}}=\mathrm{k}_{\mathrm{z}}=10^{4}[\mathrm{Nm} / \mathrm{rad}]\right)$,

- stiff rotor with high stiffness elements of blade-hub connections $\left(\mathrm{k}_{\mathrm{y}}=\mathrm{k}_{\mathrm{z}}=10^{8}[\mathrm{Nm} / \mathrm{rad}]\right)$,

where $\mathrm{k}_{\mathrm{y}}, \mathrm{k}_{\mathrm{z}}$ - stiffness of blade fixing elements in flap and lead-lag hinges respectively.

In the case of elastic rotor the stiffness of blade-hub connection is chosen to move the position of equivalent horizontal hinge to about $5 \%$ of rotor radius (see formula 12) which is in range applied for existed helicopters with non-articulated rotor hub. The stiff rotor is treated as the boundary case with extreme localization of equivalent horizontal hinge.

Changes of stiffness of the blade-hub connections influence the frequencies and eigen modes of rotor blades. The calculated values of the frequencies of rotor blade modes are collected in Table 1 .

Table 1. Eigen mode frequencies of rotor blade due to stiffness of the blade-hub connection

\begin{tabular}{|l|c|c|c|c|c|c|c|c|}
\hline \multirow{2}{*}{ rotor type } & \multicolumn{8}{|c|}{ rotor blade frequency $\left[\mathrm{v} / \omega_{\text {nom }}\right]$} \\
\cline { 2 - 9 } & F0 & F1 & F2 & F3 & C0 & C1 & T0 & T1 \\
\hline articulated & 1.019 & 2.678 & 4.189 & 6.324 & 0.260 & 4.523 & 5.861 & 16.143 \\
\hline elastic & 1.044 & 2.753 & 4.318 & 6.378 & 0.356 & 4.615 & 5.875 & 16.144 \\
\hline stiff & 1.166 & 3.117 & 5.412 & 8.325 & 0.880 & 5.914 & 6.050 & 16.212 \\
\hline
\end{tabular}

Notice: symbols used in Table 1 to sign blade eigen modes are as follows: F - out-of-plane bending mode, $\mathrm{C}$ - in-plane bending mode, $\mathrm{T}$ - torsion mode, digits after mode symbol are equal to the number of nodes, frequency values are related to the nominal rotational speed of rotor shaft $\omega_{\text {nom }}=49.65 \mathrm{rad} / \mathrm{s}$ 
Considering the blade flap oscillations, the rotor with stiff element connecting blade and hub can be, as model for analysis, replaced by an equivalent articulated rotor with the horizontal hinge located at greater distance $l_{0}$ measured from the rotor shaft axis. According to formula [12] the distance of horizontal hinge, allowing blade flapping, related to rotor radius depends on the value of frequency $\mathrm{V}_{\mathrm{F} 0}$ of the first out-of plane blade mode:

$$
\bar{l}_{0}=\frac{l_{0}}{R}=\frac{v_{F 0}^{2}-1.0}{v_{F 0}^{2}+0.5}
$$

Localization of the equivalent horizontal hinges for the elastic and stiff rotors as well distance of the real horizontal hinge for articulated rotor are given in Table 2.

Table 2. Localization of real and equivalent horizontal bearings for considered types of rotors (radius $\mathrm{R}=3.75 \mathrm{~m}$ )

\begin{tabular}{|l|c|c|c|c|}
\hline rotor & $\begin{array}{l}\text { stiffness of horizontal } \\
\text { hinge }[\mathrm{Nm} / \mathrm{rad}]\end{array}$ & $\begin{array}{l}\text { out-of-plane blade } \\
\text { frequency F0 }\end{array}$ & $\begin{array}{l}\text { distance of horizontal } \\
\text { hinge } \mathrm{I}_{0}[\mathrm{~m}]\end{array}$ & $\begin{array}{l}\text { relative localization of } \\
\text { horizontal hinge } \mathrm{1}_{0} / \mathrm{R}\end{array}$ \\
\hline articulated & 0 & 1.019 & 0.0950 & 0.02533 \\
\hline elastic & $10^{4}$ & 1.044 & 0.2103 & 0.0561 \\
\hline stiff & $10^{8}$ & 1.166 & 0.7242 & 0.1931 \\
\hline
\end{tabular}

The rise of pitching and rolling moments generated at rotor head can be expected as the result of increase the stiffness of the blade-hub connections. Striving to evaluate the range of changes of the rotor control moments, in channels of helicopter pitch and roll, the simulation calculations were conducted applying the model of deformable blade. The time-runs of pitching moments for three types of rotors, calculated at hover conditions with the same swashplate deflection equals $1^{\circ}$ related to its neutral position, are shown in Fig.2. Due to kinematics of the blade pitch control system, $1^{\circ}$ deflection of swashplate generates $1.65^{\circ}$ change of blade cyclic pitch. In the case of the elastic rotor, the swashplate deflection of $1^{\circ}$ creates the pitching moments double in size in comparison to those of the articulated rotor. The pitching moment for stiff rotor, achieved by unitary swashplate deflection, is greater than level of moments possible to be created for full swashplate deflection $\left(\varphi_{\mathrm{sw}}=5^{\circ}\right)$ in the case of articulated rotor. Comparing the time-runs of pitching moment for unitary swashplate deflection, it is noticed the large oscillations of moments for the case of stiff rotor which can be related with too high stiffness of blade-hub connections. Relating to articulated rotor, introduction of stiffness elements to elastic rotor influences an increase of bending moment at blade root sections.

The size of bending moments at blade root can be regulated by proper selection of a precone angle of blade inclination related to plane of rotation and a blade sweep angle related to radial direction. The distributions of the blade bending moments along radius, for hover conditions, due to changes of blade precone angle and sweep angle, are presented in Fig3 and Fig.4. An inadequate selection of the blade precone and sweep angles may lead to a significant increase of loads at blade root sections. Analyzing the most common states of helicopter flights the appropriated angles of blade precone and sweep can be selected for achieving the moderated level of blade loads. 


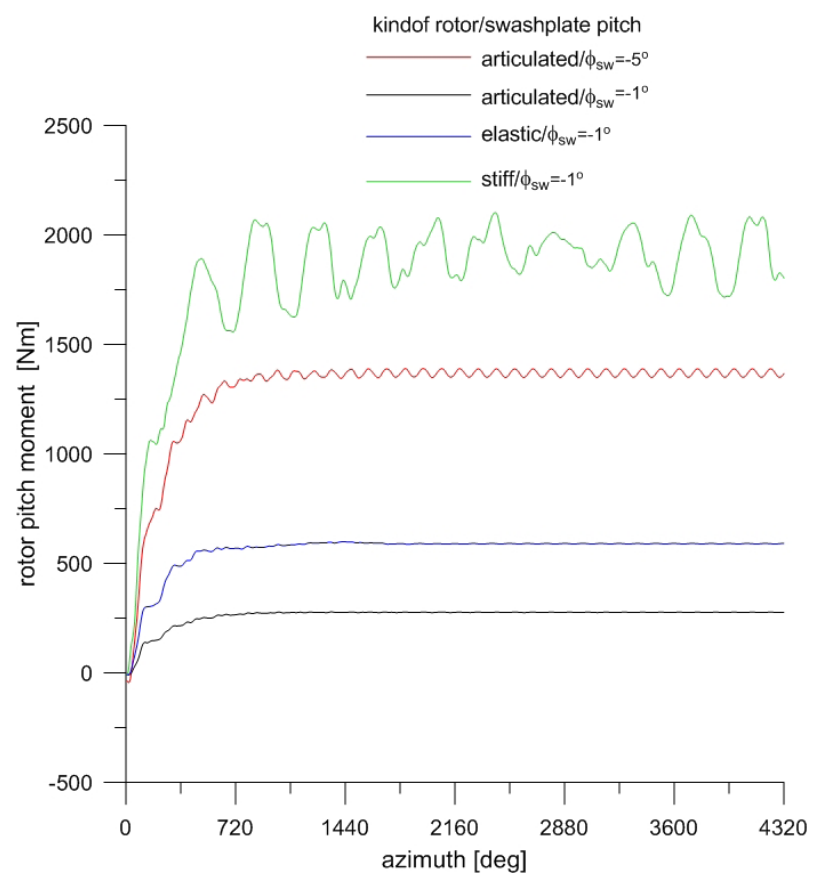

Fig. 2. Rotor pitching moment in hover condition due to type of rotor and pitch deflection of swashplate, (-) control stick pushed forward, helicopter mass $1,100 \mathrm{~kg}$, three-bladed rotor [author]

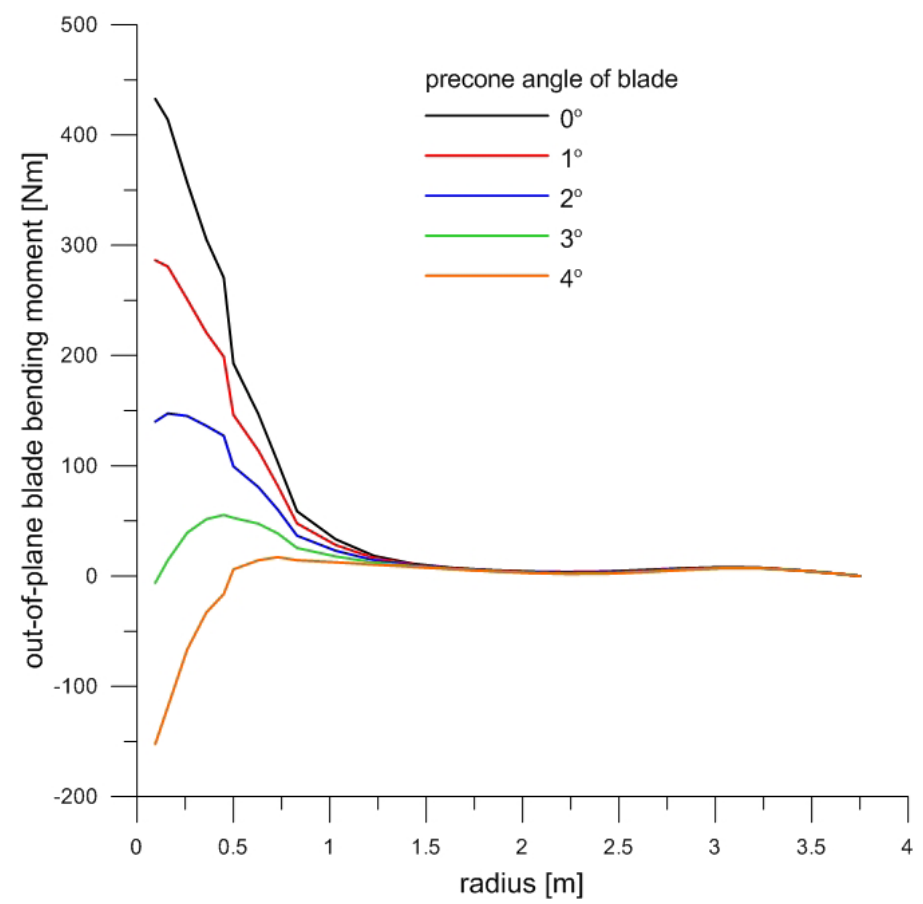

Fig. 3. In hover condition, out-of-plane blade bending moment $M_{y}$ distribution along rotor radius due to blade precone angle (flapping) [author] 


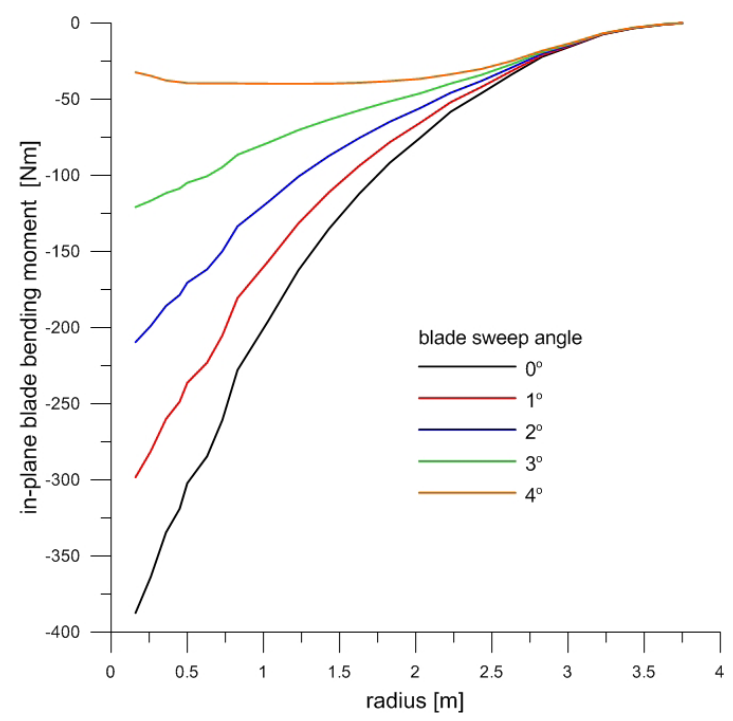

Fig. 4. In hover condition, in-plane blade bending moment $M_{z}$ distribution along rotor radius due to introduced at hub arm built-in blade sweep angle (lagging) [author]

The features of different type of rotors were compared applying the components of rotor forces, rotor moments and deflections of blades for level flight at speed of $180 \mathrm{~km} / \mathrm{h}$ as well for quasi-static state of final phase of pull-up maneuver at speed of $100 \mathrm{~km} / \mathrm{h}$. According to the results of simulation at level flight conditions, for time-runs of rotor thrust (Fig.5) and for FFT thrust spectrum (Fig.6), the similar character of thrust changes is observed for articulated and elastic type of rotors. In the thrust spectrums (Fig.6a and Fig.6b) appear lines linked with the third and the sixth harmonics of rotor speed which is typical for the three-bladed rotor. In the spectrum of the stiff rotor thrust (Fig.6c) exist the components of lower frequency than the third harmonic of rotor shaft speed which may be evidence of too low damping of blade oscillations and accompanying blade deflections affecting on increased level of thrust changes.

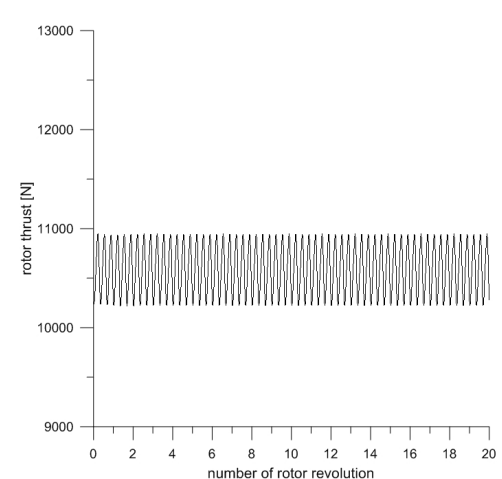

a)

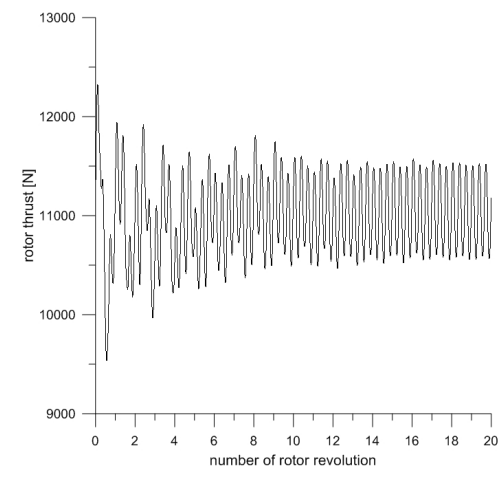

b)

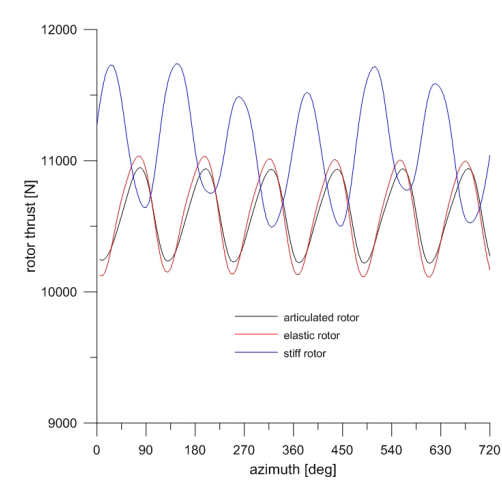

c)

Fig. 5. Thrust time-runs for three-bladed rotor in level flight conditions at speed V=180 km/h: a) articulated hub, b) stiff hub, c) comparison of $19^{\text {th }}$ and $20^{\text {th }}$ rotor revolution results for cases of articulated, elastic and stiff hub [author] 
For the stiff rotor the similar effect is noticed in spectrum of the pitching moment (Fig. 8c). In the case of the articulated and elastic rotor, the time-runs of rotor pitching moments (Fig.7) show limited oscillations. Introducing the stiffness element to the blade-hub connections causes an amplitude growth of the rotor pitching moment (Fig.8) which can increase vibrations of helicopter structure.

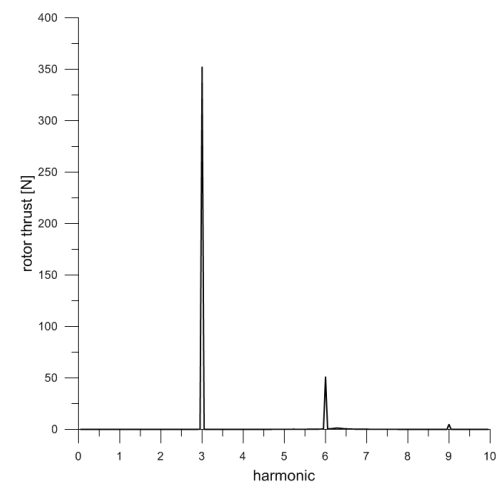

a)

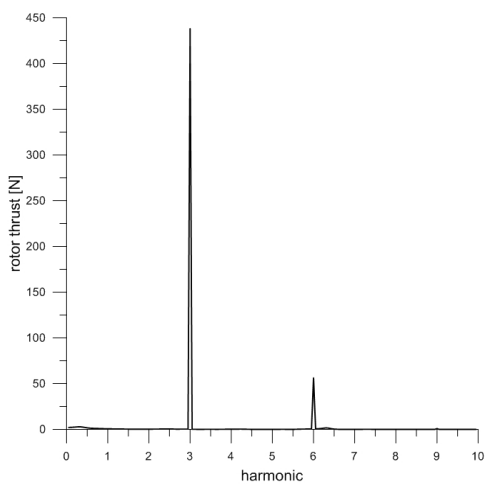

b)

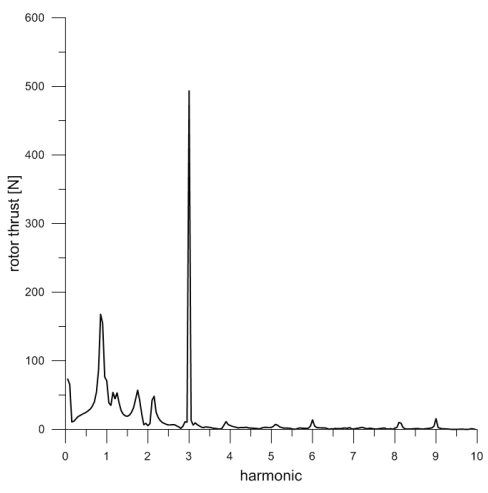

c)

Fig. 6. Thrust spectrum for three-bladed rotor in level flight conditions at speed $V=180 \mathrm{~km} / \mathrm{h}$ :

a) articulated hub, b) elastic hub, c) stiff hub [author]

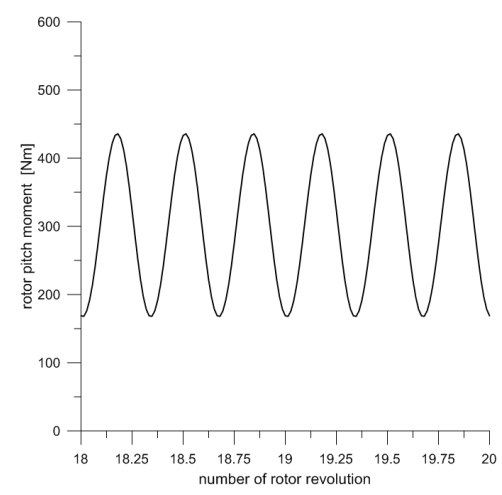

a)

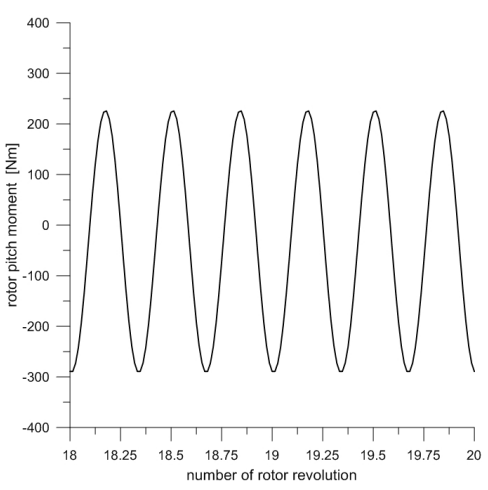

b)

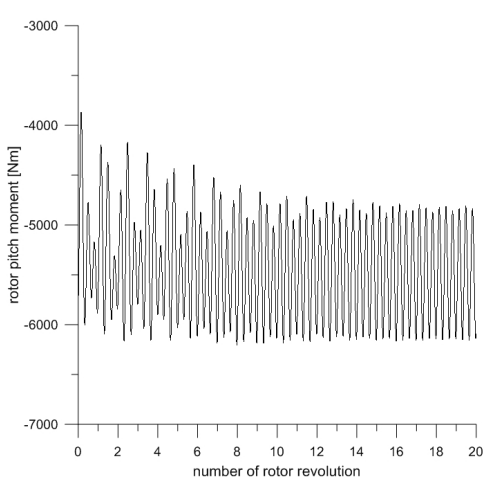

c)

Fig. 7. Time-run of pitching moment for three-bladed rotor in level flight conditions at speed $\mathrm{V}=180 \mathrm{~km} / \mathrm{h}:$ a) articulated hub, b) elastic hub, c) stiff hub [author] 


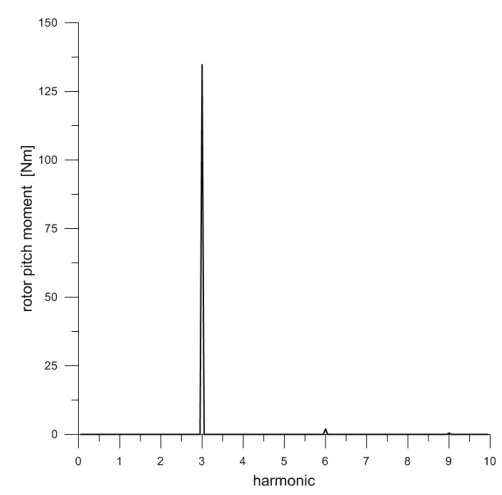

a)

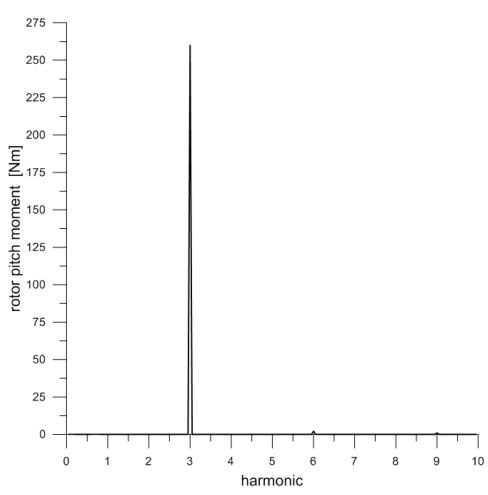

b)

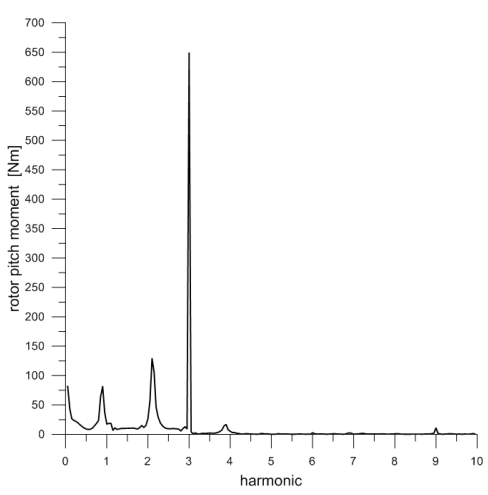

c)

Fig. 8. Pitching moment spectrum for three-bladed rotor in level flight conditions at speed V=180 km/h: a) articulated hub, b) elastic hub, c) stiff hub [author]

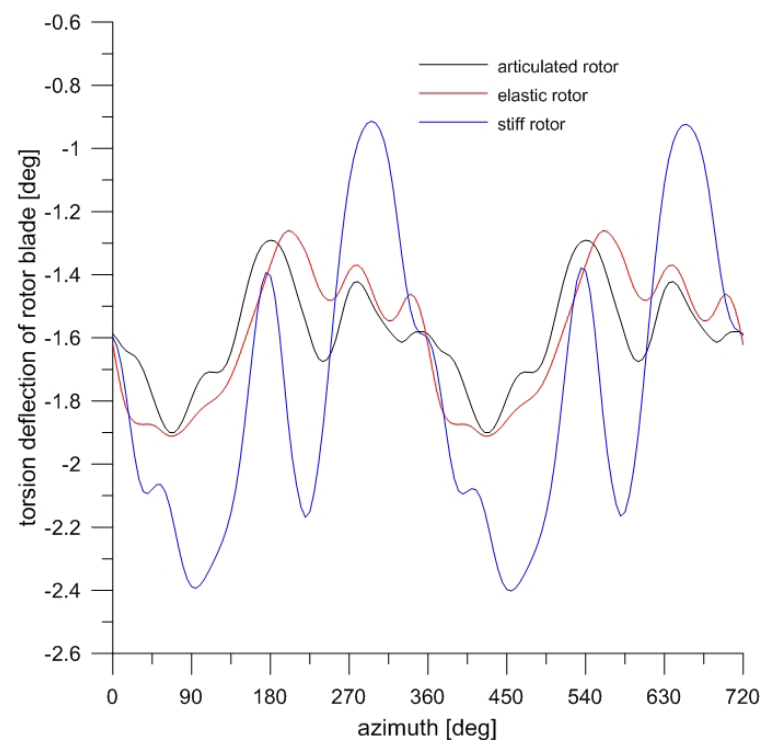

Fig. 9. Torsion deflection of rotor blade at tip section in level flight conditions at speed $\mathrm{V}=180 \mathrm{~km} / \mathrm{h}$, simulation solution for $19^{\text {th }}$ and $20^{\text {th }}$ rotor revolution [author]

In Fig. 9 the time-runs of torsion deflection at blade tip are presented for considered types of rotors in level flight at speed of $180 \mathrm{~km} / \mathrm{h}$. For articulated and elastic rotor the values of angles of blade tip deflections include in the range of $\varphi_{\text {tip }}=-1,2^{\circ} \div-1,9^{\circ}$. The blade tip deflections for the stiff rotor cover the greater range of $\varphi_{\text {tip }}=-0,9^{\circ} \div-2,4^{\circ}$. The distributions of blade torsion deflection on rotor disk are shown in Fig.10a, Fig.11a and Fig.11a for the articulated, elastic and stiff rotor respectively. In the case of articulated rotor, for level flight conditions, the zones of high blade tip torsion are observed for advancing blade at $45^{\circ} \div 90^{\circ}$ azimuth position and for retreating blade at $225^{\circ} \div 250^{\circ}$ azimuth (Fig. 10a). The distribution on rotor disk of the blade torsional deflection in the case elastic rotor (Fig.11a) is similar to one of articulated rotor. The enlarged zone of the blade azimuth positions with big torsion deflections 
$\varphi_{\text {tip }}>-1,8^{\circ}$ is found for advancing blade and for tip of retreating blade the zone of torsion deflection values limited to angle of $\varphi_{\text {tip }}=-1,3^{\circ} \div-1,4^{\circ}$ is observed. For the articulated and elastic rotors the presented results show the similar distributions of the blade out-of-plane bending moments (Fig.10b and Fig.11b). The region of blade bending with compressed the lower surface appears near azimuth position of $90^{\circ}$, the zone of bending with compressed the upper surface is visible for retreating blade. It should be noted that due to proper selection of precone angle the value of bending moment at blade root is preserved at the low level $M y<65 \mathrm{Nm}$. In the case of the stiff rotor in level flight conditions for the greater tip deflections (Fig.12a) the blade bending moments, at root sections, reach huge values (Fig.12b).

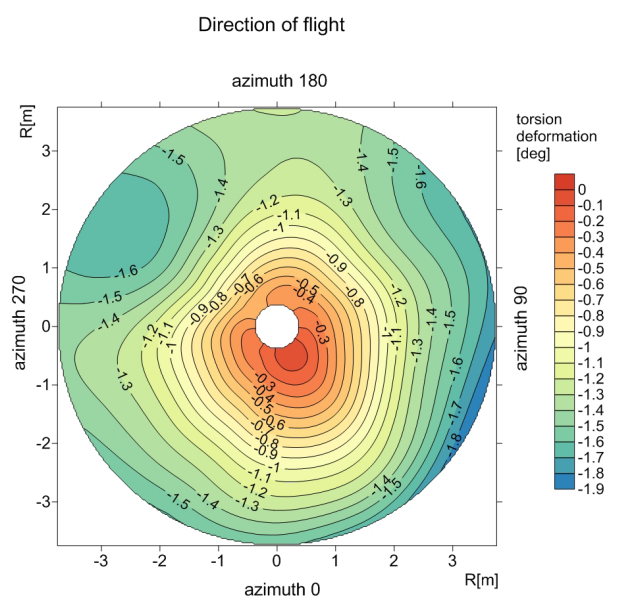

a)

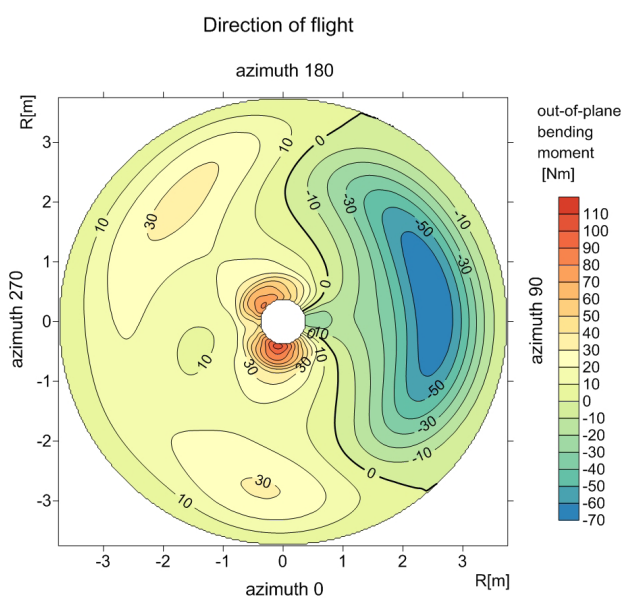

b)

Fig. 10.Rotor disk distributions for the case of articulated rotor hub in level flight $V=180 \mathrm{~km} / \mathrm{h}$ :

a) blade torsion deflection, b) blade out-of-plane bending moment [author]

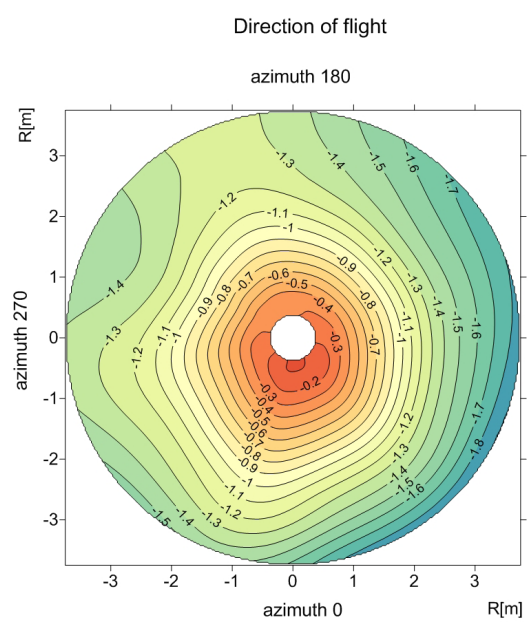

a)

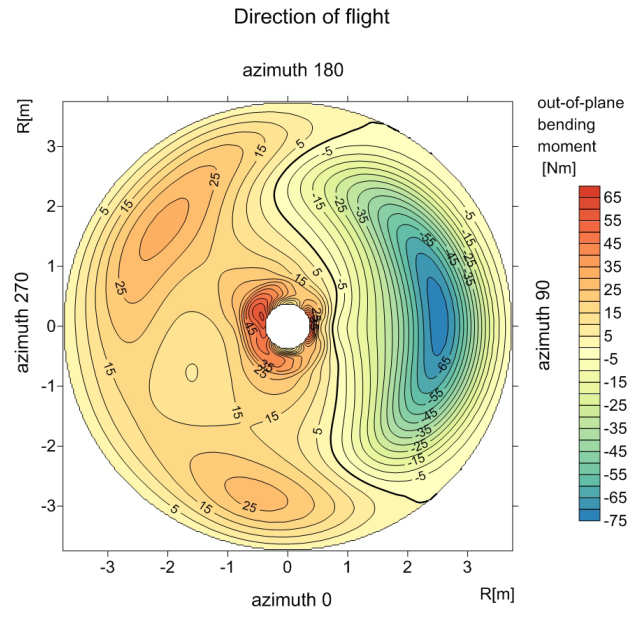

b)

Fig. 11.Rotor disk distributions for the case of elastic rotor hub in level flight $\mathrm{V}=180 \mathrm{~km} / \mathrm{h}$ :

a) blade torsion deflection, b) blade out-of-plane bending moment [author] 


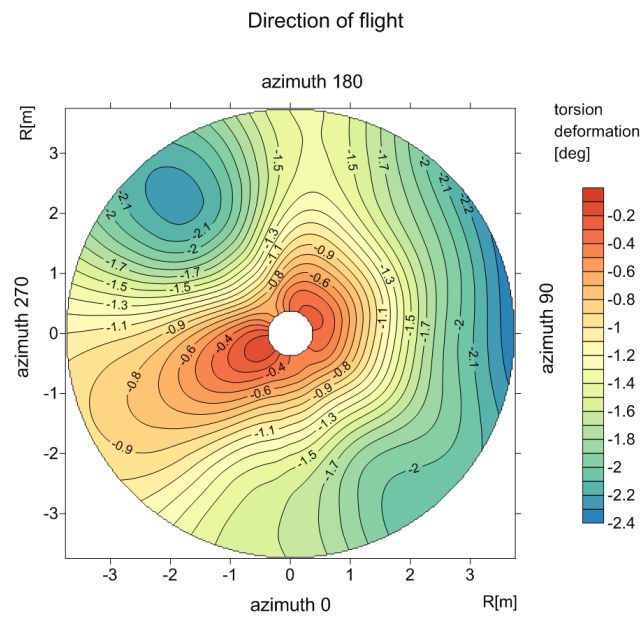

a)

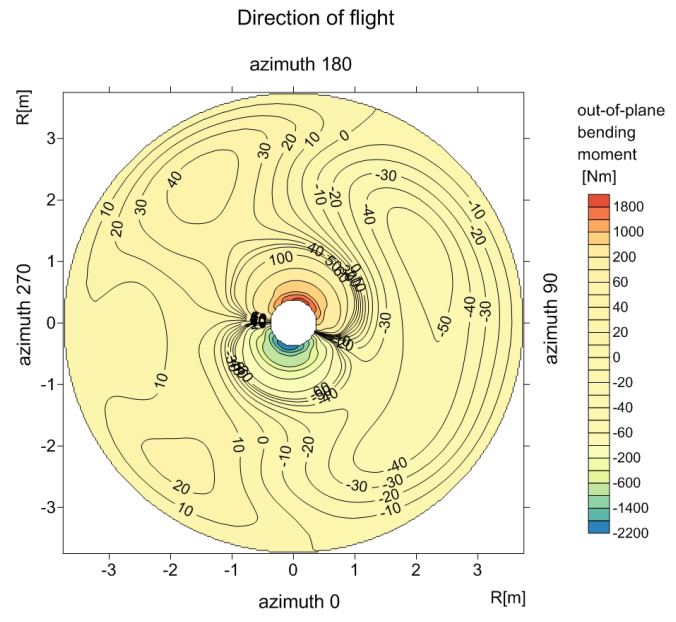

b)

Fig. 12.Rotor disk distributions for the case of stiff rotor hub in level flight $V=180 \mathrm{~km} / \mathrm{h}$ :

a) blade torsion deflection, b) blade out-of-plane bending moment [author]

The quasi-static state of final phase of pull-up maneuver at speed of $100 \mathrm{~km} / \mathrm{h}$ was analyzed applying following input conditions: axis of rotor shaft pitched-up at angle of $15^{\circ}$ in respect to the vertical position, increased blade pitch collective angle, pitch angle of swashplate related to pulled-up cyclic stick position. For the pull-up conditions the size of calculated rotor thrust increased by about 50 percent in comparison to value for level flight conditions (Fig.5c andFig.13). The growth of rotor loads is accompanied by enlarged blade deflections. It is supposed that in the case of quasi-static state, the calculated rotor loads could reach higher values compared to real maneuver conditions due to lack of effects of inertial forces which are generated as results of accelerations acting on helicopter body.

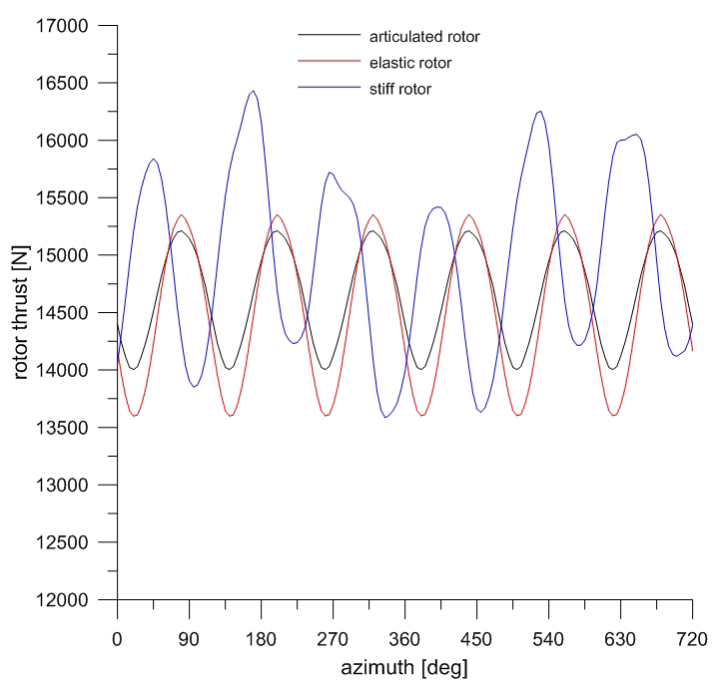

Fig. 13. Rotor thrust for different type of hub during final phase of pull-up maneuver at speed $\mathrm{V}=100 \mathrm{~km} / \mathrm{h}$, simulation solution for $19^{\text {th }}$ and $20^{\text {th }}$ rotor revolution [author] 
For pull-up simulations, the similar time-runs of blade tip deflections were received for the articulated and elastic rotor cases. The comparison of blade torsion deformations for simulation solutions of the pull-up maneuver for different rotor hubs are presented in Fig.14. The blades of the stiff rotor are subjected to clearly bigger deflections. The similarity of blade deflections in pull-up conditions can be noticed comparing the distributions on rotor disk of the blade torsion deflections (Fig.15a and Fig.15b), where the zone of large deflections is moved to region of retreating blade. In the level flight at higher speed of $180 \mathrm{~km} / \mathrm{h}$ the zone of big blade torsion deflections is located at site of the advancing blade (Fig.10a and Fig.11a). In the case of stiff rotor pull-up the biggest blade torsion deflections are noticed for retreating blade at radius position nearly the blade tip (Fig. 15c). Analyzing the distribution of blade deflections for the stiff rotor, it can be noticed that after quick reduction of blade torsion deflections at range of azimuth from $270^{\circ}$ to $0^{\circ}$, during following rotation at area of half of rotor disk (azimuths $0^{\circ}-90^{\circ}-180^{\circ}$ ), the blade torsion oscillations of frequency equals the first torsion mode $\left(v / \omega_{\text {nom }}=6.05\right)$ are observed. Increased blade deflections and loads for the stiff rotor, comparing to articulated and elastic rotors, results in enlarged level of vibrations transmitted from rotor to fuselage of helicopter.

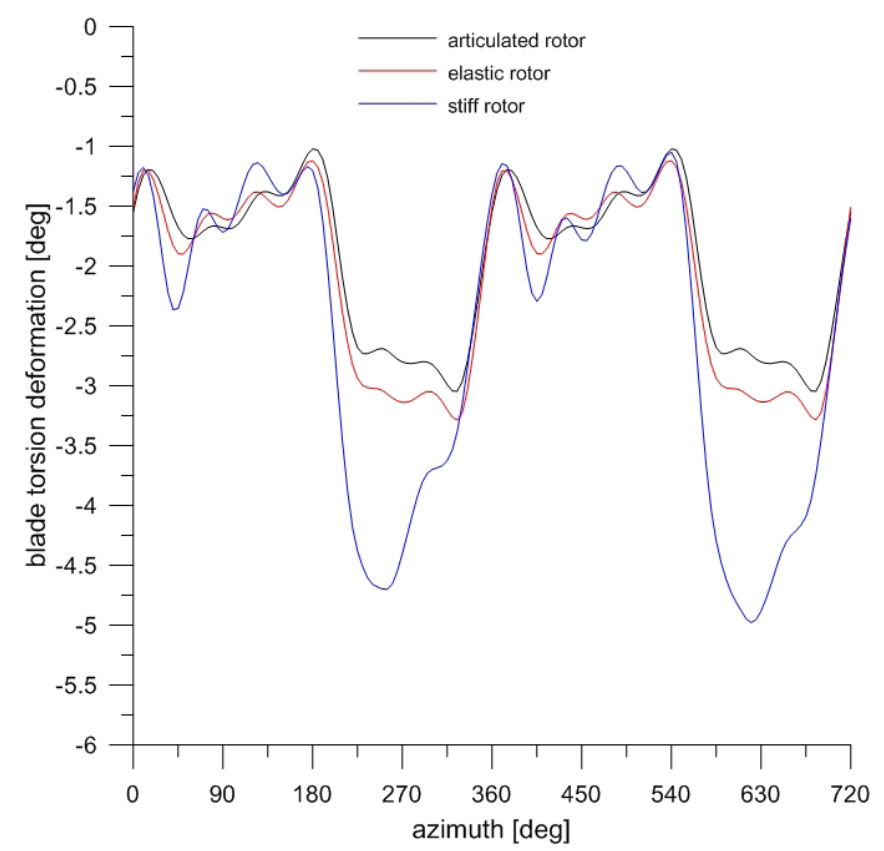

Fig. 14. Blade torsion deflection for different types of rotor hub during final phase of pull-up maneuver at speed $\mathrm{V}=100 \mathrm{~km} / \mathrm{h}$, simulation solution for $19^{\text {th }}$ and $20^{\text {th }}$ rotor revolution [author] 


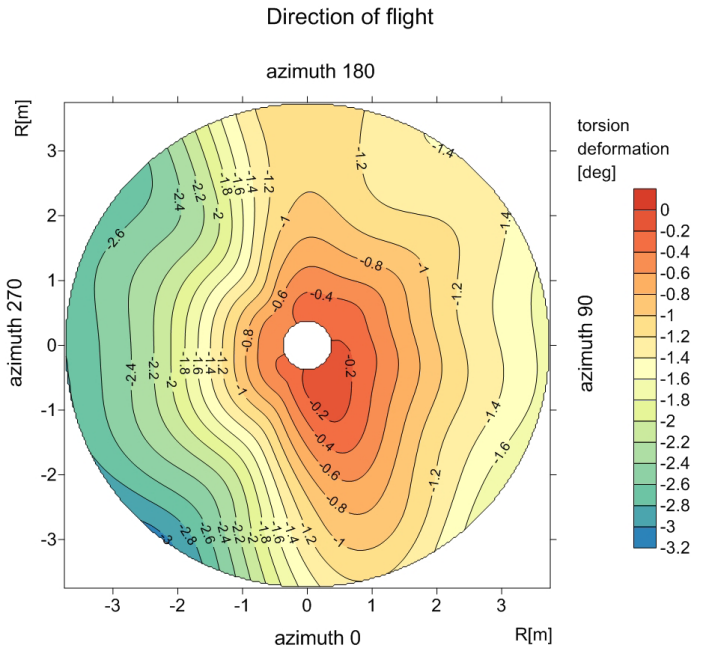

a)

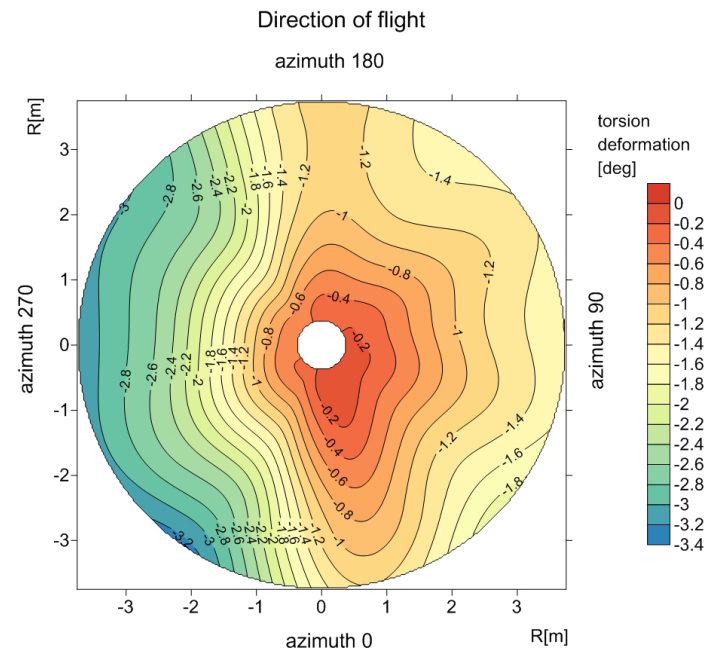

b)

Fig. 15. Rotor disk distribution of blade torsion deflection in final phase of pull-up maneuver at speed $V=100 \mathrm{~km} / \mathrm{h}$ for different rotor; a) articulated hub, b) elastic hub [author]

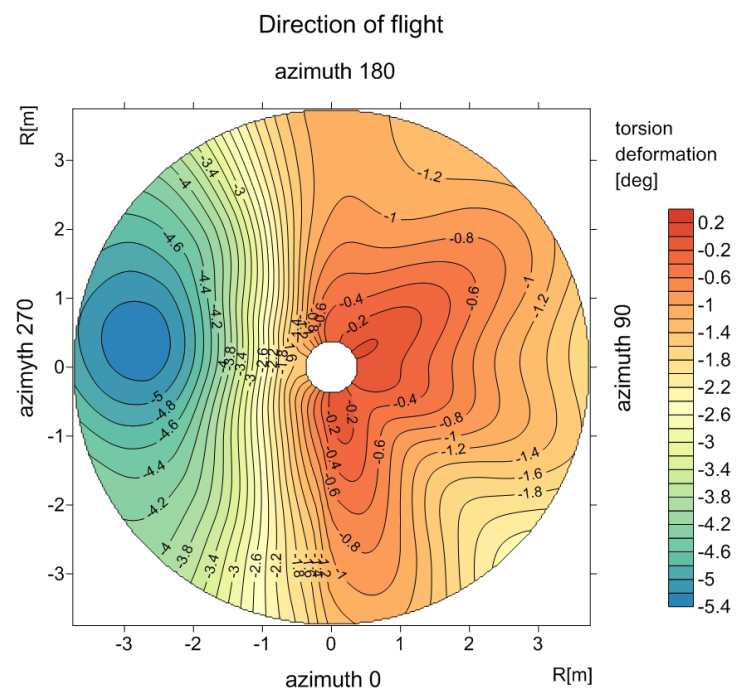

Fig. 15c. Rotor disk distribution of blade torsion deflection in final phase of pull-up maneuver at speed $\mathrm{V}=100 \mathrm{~km} / \mathrm{h}$ for rotor with stiff hub [author]

\section{CONCLUSIONS}

In the scope of simulation research of rotor features, the results of calculations allow to compare the three types of rotors with different stiffness of blade-hub connections: articulated, elastic and stiff rotors. The calculations were performed for selected flight conditions of helicopter: hover, level flight and pull-up. The set of blades of the same aerodynamic, mass and stiffness data was applied for all rotors. Originally the blades were designed for helicopter with articulated rotor. 
The simulations concerning the elastic rotor indicate that modification of the rotor head including the element of blade-hub connection of moderate stiffness results in limited growth of blade loads and deflections preserving its size at level similar to the case of articulated rotor. The elastic rotor also enables generation at hub larger pitching and rolling moment which improve control of helicopter especially in phase of maneuvers when the size of rotor thrust can be reduced.

Application of elastic rotor may cause the higher level of fuselage vibrations due to increased components of rotor loads transmitted to non-rotating body of helicopter. In the same flight conditions the calculated blade loads and deflections reach the similar level for considered versions of articulated and elastic rotors. It seems that idea of applying the rotor blade, initially designed for articulated rotor, as parts of elastic rotor is possible for realization.

\section{REFERENCES}

[1] Prouty R.W., 1988, More Helicopter Aerodynamics, Phillips Pub Co.

[2] Johnson W., 1980, Helicopter Theory, Princeton University Press, Princeton, New Jersey.

[3] Padfield G.D., 1996, Helicopter Flight Dynamics. the Theory and Application of Flying Qualities and Simulation Modeling, Blackwell Publishing Ltd.

[4] Warwick G., 1985, "Will rotors lose their bearings?", Flight International, 29 June, no. 3966, vol.127, pp. 30-35.

[5] Braun D., Frommlet H., Schwarz A.,1990, “FEL - A New Main Rotor System”, Vertica, Vol. 14, No. 1, pp. 47-60.

[6] Schmit-Creton V., 2006, Successful Maiden Flight, Rotor on Line - A publication of Eurocopter, July/August, No. 67, from http://www.airbushelicopters.com/w1/jrotor/67

[7] Wilson M., 1974, "Westland-Aerospatiale Lynx", Flight International, 29 August, No. 3416, Vol. 106, Supplement 1, pp. 19-22.

[8] Yeo H., Johnson W., 2005, "Comparison of Structural Loads Calculated Using Comprehensive Analysis", $31^{\text {st }}$ European Rotorcraft Forum, Florence, Italy, September 13-15.

[9] Nguyen K., Lauzon D., Anand V., 1994, "Computation of Loads on the McDonnell Douglas Advanced Bearingless Rotor", American Helicopter Society 50th Annual Forum, Washington D.C., May 11-13.

[10] Gula P., Gorecki T., 2013,"Design, Experiments and Development of a Polish Unmanned Helicopter ILX-27", 39th European Rotorcraft Forum, Moscow, Russia, 3-6 September.

[11] Stanisławski J., 2015, "Pattern of Helicopter Rotor Loads and Blade Deformations in Some States of Flight Envelope", Transactions of the Institute of Aviation, No.1(238), pp. 70-90.

[12] Stanisławski J., 2016, "Simulation Investigation of Aerodynamic Effectiveness Reduction of Helicopter Tail Rotor”, Transactions of the Institute of Aviation, No.1(242) , pp. 36-56. 


\section{PORÓWNANIE WŁASNOŚCI WIRNIKA NOŚNEGO ŚMIGŁOWCA PRZY RÓŻNEJ SZTYWNOŚCI POŁĄCZENIA LOPATY Z GLOWICĄ WIRNIKA}

\section{Streszczenie}

W pracy przedstawiono wyniki obliczeń symulacyjnych dotyczących wpływu sztywności połączenia łopat z głowicą na poziom obciążeń wirnika i odkształceń łopat w warunkach zawisu, lotu poziomego i wyrwania. Przyjęto trzy wersje wirnika nośnego z przegubowym, sprężystym i sztywnym połączeniem łopat i głowicy. Dla wszystkich przypadków wirnika przyjęto łopaty identycznym rozkładzie sztywności, mas i charakterystyk aerodynamicznych. Obciążenia wirnika nośnego wyznaczano rozwiązując metodą Runge-Kutta równania ruchu odkształcalnych łopat z uwzględnieniem metody Galerkina, gdzie parametry ruchu łopat traktowano jako złożenie giętnych i skrętnych postaci własnych łopat. Wyniki symulacyjne wskazują na możliwość generacji większych momentów sterujących wirnika i poprawę manewrowości śmigłowca w przypadku zabudowy niezmienianej łopaty wirnika przegubowego w zespole z głowicą sprężystą.

Słowa kluczowe: śmigłowiec, wirnik nośny, odkształcenia łopat. 